Agro-Science Journal of Tropical Agriculture, Food, Environment and Extension Volume 8 Number 3 September 2009 pn 151-161

ISSN 1119-7455

\title{
THE EFFECTS OF ORGANIC AND INORGANIC FERTILIZERS ON GROWTH, YIELD AND BLACK SIGATOKA DISEASE REACTION OF SOME PLANTAIN (MUSA SPP. AAB) GENOTYPES IN SOUTH-EASTERN NIGERIA.
}

\author{
Ndukwe. ${ }^{1}$, O. O, Muoneke ${ }^{1}$, C. O. ${ }^{*}$ Baiyeri,${ }^{2 *}$ K. P. and Tenkouano, ${ }^{3}$ A. \\ ${ }^{1}$ Department of Agronomy, Michael Okpara University of Agriculture, \\ Umudike, Abia State, Nigeria. \\ ${ }^{2}$ Department of Crop Science, University of Nigeria, Nsukka, Nigeria. \\ ${ }^{3}$ International Institute of Tropical Agriculture, High Rainfall Station, \\ Onne, Rivers State, Nigeria.
}

*Authors for all correspondence: paulkayodebaiyeri@yahoo.com

cosmuoneke@yahoo.com

\begin{abstract}
Three plantain hybrids ('29525', '30456-3', 'PITA 14') and a landrace genotype 'Agbagba' (as control) were field evaluated in response to organic and inorganic fertilizers at the International Institute of Tropical Agriculture, High Rainfall Station, Onne, Rivers State, Nigeria, for two cropping cycles. The experimental design was a $4 \times 3$ factorial in randomized complete block, replicated thrice. Growth, yield and black sigatoka disease parameters were measured during the two cropping (plant and ratoon crop) cycles of evaluation. The genotypes ' 29525 ' and 'PITA 14' produced significantly $(P<0.05)$ higher leaf area, number of standing leaves and index of non-spotted leaves; however, genotype '30456-3' retained more functional leaves at harvest while genotype '29525' produced heavier bunches/ha during the two cropping cycles. Poultry manure supported the best plant growth and yield parameters, especially index of non-spotted leaves, number of standing leaves at flowering and at harvest, leaf retention index and bunch yield/ha. There was a strong and positive relationship between the index of non-spotted leaves and bunch yield/ha. The newly developed hybrids ('29525' and '30456-3') were confirmed to be tolerant to black sigatoka disease with fertilizer application reducing the severity of the disease. Similarly, these two new hybrids had comparatively good agronomic traits that could warrant their recommendation for on-farm adaptive trial.
\end{abstract}

Keywords: Musa genotypes, Fertilizer, Black Sigatoka disease, Growth, Yield.

\section{INTRODUCTION}

Plantain is one of the major staple foods for over 100 million people in sub-Saharan Africa (Englberger et al., 2006). FAO (2006) reported that the world production of plantains and bananas was about 100 million metric tonnes.

Black sigatoka disease, first described as black leaf streak in the Sigatoka Valley in Fiji in 1963 (Rhodes, 1964) is the most important constraint to plantain and banana production worldwide and endangers the food security of the resource-limited farmers (Craenen, 1998; PasbergGauhl et al., 2000). This disease is caused by the ascomycete fungus, Mycosphaerella fijiensis Morelet. Mobambo et al. (1993) reported yield loss of 33 to $50 \%$ caused by black Siagtoka disease in West Africa. Plants are severely defoliated by the disease and a decrease in functional leaf area results in yield loss through a reduction of fruits per bunch and lower fruit weight (Mobambo et al., 1993). Black siagtoka disease also causes delayed flowering and harvest, and premature fruit ripening. The intensive use of fungicides is required in commercial plantain production but fungicides are very harmful to the environment in addition to the production costs and the appearance of fungicideresistant strains of the pathogen. Hence, chemical control may not be feasible for increased production by resource-limited farmers. The utilization of resistant Musa cultivars is a more appropriate solution to control black sigatoka disease (Vuylsteke et al., 1993; Tomekpe et al., 1999). Since 1987, breeding was initiated by International Institute of Tropical Agriculture (IITA) to develop germplasm with durable black sigatoka resistance as well as develop plantain hybrids resistant to black sigatoka. 'PITA 14', '29525' and '30456-3' are some of the tetraploid 
hybrids developed by IITA. Whereas 'PITA 14' has undergone multilocational and on-farm adaptive trials (Baiyeri and Tenkouano, 2007) the genotypes '29525' and '30456-3'are newly selected materials which have not undergone such trials.

High soil fertility status is associated with lower black sigatoka disease severity on plantain (Mobambo et al., 1994). This is expressed by the plant through having a higher number of standing leaves and less leaf area with black sigatoka symptoms (Mobambo et al., 1994). Besides, an understanding of plant response pattern to soil fertility is an important agronomic index for sustainable production under regular cultivation culture especially in farmers' field.

Thus, this experiment was carried out to [i] evaluate the black sigatoka disease responses of the newly developed hybrids in comparison with the IITA adopted hybrid ('PITA 14') and the susceptible Nigerian landrace, 'Agbagba'; and [ii] determine the growth and yield responses of these genotypes to organic and inorganic fertilizers.

\section{MATERIALS AND METHODS}

The experiment was carried out in IITA, High rainfall station, Onne, Rivers State, Nigeria. The location is on latitude $04^{\circ} 43^{\prime} \mathrm{N}$, longitude $07^{\circ}$ $01^{\prime} \mathrm{E}$ and $10 \mathrm{~m}$ altitude, the site is characterized by an ultisol derived from coastal sediments; soil has low $\mathrm{pH}$ of 5.3 and low cation exchange capacity. The area has a uni-modally distributed annual rainfall of about $2400 \mathrm{~mm}$. The location is also associated with high relative humidity with average values ranging from $78 \%$ in February to $89 \%$ in July and September (Ortiz et al., 1997). The physico-chemical properties of the soil of the study area and the poultry manure used for the study are as shown in Table 1.

The experiment was a $4 \times 3$ factorial arranged in a randomized complete block design with three replications. Four plantain genotypes comprising three tetraploid hybrids ('29525', '30456-3', 'PITA 14') and a triploid landrace, as control, ('Agbagba') constituted the first factor. The second factor comprised two fertilizer types and a control (poultry manure, inorganic fertilizer and no fertilizer). The plants were obtained through micro propagation at IITA and planted in a singlerow plot of five plants replicated thrice per treatment combination. The planting density was 1667 plants/ha with a spacing of $3 \mathrm{~m}$ between rows and $2 \mathrm{~m}$ within row. These plants were screened under natural field condition. Urea $(300 \mathrm{~kg} / \mathrm{ha}$ nitrogen) and muriate of potash $\left(550 \mathrm{~kg} / \mathrm{ha} \mathrm{K}_{2} \mathrm{O}\right)$ applied in six-split doses were used as inorganic fertilizer as recommended by Swennen and De Langhe (1985) and $20 \mathrm{t} /$ ha of poultry manure was used as organic fertilizer. Half dose of the poultry manure was applied at planting and the remaining applied as top dressing at six months after planting.

The planting holes measured $40 \mathrm{~cm} \mathrm{x} 40$ $\mathrm{cm} \times 40 \mathrm{~cm}$ and each of the holes, before planting received $15 \mathrm{~g}$ of Furadan $5 \mathrm{G}$ for the control of plantain weevil (Cosmopolites sordidus) and rootknot nematodes (Obiefuna,1984). One follower sucker, as ratoon plant was always maintained after flowering. De-suckering was repeated at every 4-6 weeks. Weeding was carried out using herbicide ('round-up') and slashing, when necessary. Pruning of dead leaves was done every 2-3 weeks. Other agronomic management done were carried out as recommended by Swennen (1990). Growth data were measured at three and six months after planting (MAP), and at flowering; data on yield and yield attributes were measured at harvest. The following parameters were recorded at 3 and 6 MAP - plant height, plant girth, number of standing leaves (fresh and erect leaves), total leaf area of the three topmost leaves (Obiefuna and Ndubuizu, 1979; Baiyeri and Tenkouano, 2008). At flowering, plant height, plant girth taken at $100 \mathrm{~cm}$ above the ground level, number of standing leaves, youngest leaf spotted with black sigatoka disease (the youngest leaf, counting from the top showing the first symptoms of black sigatoka disease), and height of tallest sucker were recorded. At harvest, the number of standing leaves, total weight of the standing leaves, bunch yield per hectare, number of fruit per bunch and the fruit weight were collected. From the primary parameters measured, the index of non-spotted leaf (INSL) and leaf retention index were calculated. The INSL was calculated as the ratio between youngest leaf spotted at flowering (YLSF) and the total number of standing leaves at flowering (NSLF) (Craenen, 1998).

$\mathrm{INSL}=((\mathrm{YSLF}-1) / \mathrm{NSLF}) \times 100$

The leaf retention index (LRI) was calculated as ratio between the number of standing (green) leaves at harvest (NSLH) and the total number of standing (green) leaves at flowering (Baiyeri et al., 2008).

$\mathrm{LRI}=(\mathrm{NSLH} / \mathrm{NSLF}) \times 100$

All the data collected were subjected to analysis of variance using GENSTAT (2003) and least significant difference (LSD) test at 5\% probability level was used to compare the means. The Pearson's multiple correlation analyses using SPSS release 15.0 (SPSS, 2006) was used to assess correlations among some parameters. 


\section{RESULTS}

The physicochemical properties of the experimental site and the nutritional quality of the poultry manure applied are shown in Table 1 . The soil was sandy loam, acidic and relatively low in cations. The poultry manure was however, high in essential plant nutrients.

Analysis of variance (Table 2) showed that genotype significantly $(\mathrm{P}<0.05)$ influenced most parameters, except youngest leaf spotted at flowering. Fertilizer type was significant for total leaf area, youngest leaf spotted at flowering, index of non-spotted leaves at flowering, number of standing leaves at harvest, total leaf weight, leaf retention index, bunch yield/ha and number of fruits/bunch. The genotype-by-fertilizer type interaction effect was significant for total leaf area, height of tallest sucker at flowering, number of standing leaves, total leaf weight, leaf retention index, bunch yield/ha and fruit weight but not for plant height and girth (Table 2).

Plant responses at vegetative growth and flowering stages:

Genotype effect: 'PITA 14' and '29525' had better growth at 3 and 6 MAP (Table 3). 'PITA 14' had taller plants while '29525' had better foliage parameters. These genotypes also had thicker pseudostems at both 3 and 6 MAP. The genotype ' $30456-3$ ' had the lowest of all the growth parameters (Table 3). Table 4 shows the host response to growth and black sigatoka disease at flowering of the plant and ratoon crops. In the plant crop, 'Agbagba' produced tallest plants and thickest plant girth while 'PITA 14' and '29525' had similar but highest tolerance to sigatoka disease, as indicated by the index of non-spotted leaves and youngest leaf spotted at flowering. However, '30456-3' produced tallest follower sucker. In the ratoon crop, 'Agbagba' and 'PITA 14' had similar but tallest plants. 'PITA 14' and '30456-3' had similar but healthier leaves (high index of non-spotted leaves and youngest leaf spotted at flowering) whereas plant girth was similar and higher for all the genotypes except '30456-3'.

Table 1 Physicochemical properties of the experimental site and poultry manure sample utilized Fort he study

\begin{tabular}{llll}
\hline & Top soil $(0-15 \mathrm{~cm})$ & Sub-soil $(15-30 \mathrm{~cm})$ & Poultry manure \\
\hline Chemical properties & & & 15.6 \\
Nitrogen $(\mathrm{g} / \mathrm{kg})$ & 1.3 & 0.7 & 14.0 \\
Phosphorus $(\mathrm{mg} / \mathrm{kg})$ & 49.10 & 66.31 & 17.9 \\
Potassium $(\mathrm{g} / \mathrm{kg})$ & 1.4 & 1.5 & 3.76 \\
Calcium $(\mathrm{cmol} / \mathrm{kg})$ & 2.06 & 0.72 & 0.41 \\
Magnesium $(\mathrm{cmol} / \mathrm{kg})$ & 0.13 & 0.03 & $\mathrm{Nd}$ \\
CEC $(\mathrm{cmol} / \mathrm{kg})$ & 3.19 & 3.02 & 11.36 \\
Zinc $(\mathrm{mg} / \mathrm{kg})$ & 4.26 & 3.87 & $\mathrm{Nd}$ \\
Copper $(\mathrm{mg} / \mathrm{kg})$ & 0.72 & 1.08 & 313.22 \\
Iron $(\mathrm{mg} / \mathrm{kg})$ & 150.13 & 196.65 & \\
& & & $\mathrm{Nd}$ \\
Physical properties & & 4.73 & $\mathrm{Nd}$ \\
pH $\left(\mathrm{H}_{2} 0\right)$ & 5.30 & 0.90 & $\mathrm{Nd}$ \\
Organic carbon $(\%)$ & 1.37 & 70.00 & $\mathrm{Nd}$ \\
Sand $(\%)$ & 76.67 & 6.67 & $\mathrm{Nd}$ \\
Silt $(\%)$ & 8.00 & 22.67 & \\
Clay $(\%)$ & 15.33 & & \\
Textural class & Sandy loam & & \\
\hline nd= Not determined & & & \\
\hline
\end{tabular}

nd $=$ Not determined 
Table 2: ANOVA showing sources of variation, degree of freedom and mean square for various parameters in the plant crop

\begin{tabular}{|c|c|c|c|c|c|c|c|c|c|c|c|c|c|}
\hline Sources & Df & $\begin{array}{l}\text { PHT } \\
(\mathrm{cm})\end{array}$ & $\begin{array}{l}\mathrm{PG} \\
(\mathrm{cm})\end{array}$ & TLA $\left(\mathrm{m}^{2}\right)$ & YLSF & $\begin{array}{l}\begin{array}{l}\text { INSLF } \\
(\%)\end{array} \\
\end{array}$ & $\begin{array}{l}\text { HTSF } \\
(\mathrm{cm})\end{array}$ & NSLH & TLWT (kg) & $\begin{array}{l}\text { LRI } \\
(\%)\end{array}$ & BWT (t/ha) & NFB & $\begin{array}{l}\text { FWT } \\
(\mathrm{g})\end{array}$ \\
\hline Replication & 2 & $1607.60^{* *}$ & $70.44 * *$ & $0.10^{* *}$ & $6.84 * *$ & $45.27 * *$ & $7066.60^{* *}$ & $5.58 * *$ & $3.76 * *$ & $339.27 * *$ & $16.90^{* * *}$ & $66.69^{* *}$ & $1610.00^{* *}$ \\
\hline $\begin{array}{l}\text { Genotype } \\
\text { (G) }\end{array}$ & 3 & $11133.70^{* * *}$ & $183.09^{* *}$ & $0.93 * *$ & $3.30^{\mathrm{ns}}$ & $271.63 * * *$ & $3450.10^{*}$ & $7.27 * * *$ & $5.46^{* * *}$ & $525.52 * * *$ & $214.14 * * *$ & $30716.50 * * *$ & $39220.00 * *$ \\
\hline $\begin{array}{l}\text { Fertilizer } \\
\text { type (F) }\end{array}$ & 2 & $393.80^{\text {ns }}$ & $7.60^{\mathrm{ns}}$ & $0.46^{* *}$ & $21.55 * * *$ & $211.83 * *$ & $1845.70^{\mathrm{ns}}$ & 7.48 *** & $4.71 * * *$ & $554.37 * * *$ & $46.78^{*}$ & $670.59 * *$ & $1443.00^{\mathrm{ns}}$ \\
\hline GxF & 6 & $533.80^{\mathrm{ns}}$ & $14.54^{\mathrm{ns}}$ & $0.10^{* *}$ & $2.22^{\mathrm{ns}}$ & $33.43^{\text {ns }}$ & $4233.40^{* *}$ & $3.42^{* * * *}$ & $2.10^{* *}$ & $349.41 * * *$ & $43.59^{*}$ & $194.45^{\mathrm{ns}}$ & $4414.00^{*}$ \\
\hline Error & 22 & 332.20 & 27.01 & 0.03 & 1.85 & 22.95 & 994.10 & 0.48 & 0.39 & 49.40 & 10.75 & 90.01 & 1623.00 \\
\hline Total & 35 & - & - & - & - & - & - & - & - & - & - & - & \\
\hline
\end{tabular}

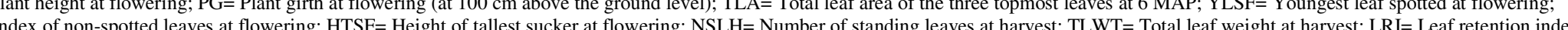

$\mathrm{BWT} / \mathrm{ha}=$ Bunch yield/ha; NFB= Number of fruits/bunch; FWT= Fruit weight; $* * *, * * *=$ Significant at $5 \%, 1 \%$ and $0.1 \%$ probability level respectively; ns= Non-significance. 
Fertilizer type effect: The plant height, plant girth and height of tallest sucker at 3 MAP were significantly higher with the application of poultry manure than inorganic fertilizer or no fertilizer application (Table 3). At 6 MAP, application of either poultry manure or inorganic fertilizer produced taller plants and suckers as well as wider pseudostem than no fertilizer application. However, there was no significant difference between poultry manure and inorganic fertilizer application (Table 3). The number of standing leaves was similar in both 3 and 6 MAP. The application of organic (poultry) manure in the plant crop supported higher tolerance to black sigatoka disease than the inorganic fertilizer or no fertilizer application, as indicated by the index of nonspotted leaf and youngest leaf spotted (Table 4). Plant height and girth was highest for 'Agbagba' in the ratoon crop. All the other parameters were statistically similar among the fertilizer types.

Interaction effect: At 3 MAP, the application of poultry manure produced significantly $(\mathrm{P}<$ 0.05) bigger pseudostem in ' 29525 ' than the other treatment combinations. At 6 MAP, the photoactive leaf area was widest for ' 29525 ' when it received inorganic fertilizer (Table 5). The genotype, '30456-3,' produced significantly lower values for plant girth and leaf area irrespective of the fertilizer type. At flowering, the interaction only influenced the height of tallest sucker in the plant crop (Fig.
1). Tallest follower sucker was produced by '30456-3' in all the fertilized plots.

\section{Plant responses at harvest:}

Genotype effect: In the plant crop, the number of standing leaves and total leaf weight were higher for '30456-3' and 'Agbagba' than the other genotypes (Table 6). However, these parameters were similar among the genotypes in the ratoon crop. The leaf retention index was similar but significantly $(\mathrm{P}<0.05)$ higher for '30456-3' and '29525' in the plant crop, though in the ratoon crop, '30456-3' significantly $(\mathrm{P}<0.05)$ retained more leaves than the other genotypes. The genotype '29525' produced the heaviest bunch and highest number of fruits but Agbagba had heaviest fruits than the other genotypes in both the plant and ratoon crops (Table 6).

Fertilizer type effect: The application of fertilizer influenced the yield and black sigatoka disease parameters at harvest in the plant crop only (Table 6). In the plant crop, higher number of leaves, leaf weight, leaf retention index, number of fruits and heavier bunches were produced by the application of organic (poultry) manure. All the parameters measured were statistically similar in the ratoon crop (Table 6). However, it was notable that the application of poultry manure produced extra 4.2 and 3.7-t/ha fruit yield than the control (no fertilizer) and inorganic fertilizer treatments, respectively, in the ratoon cycle.

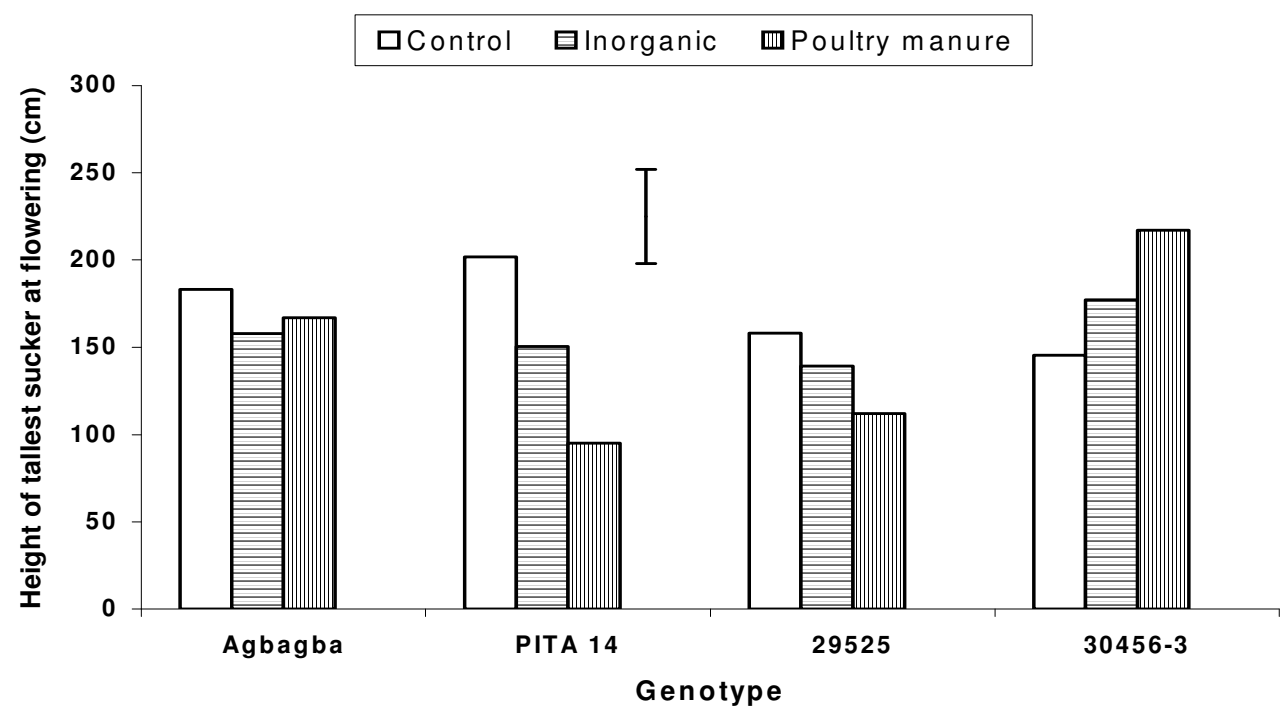

Fig. 1: Genotype and fertilizer type interaction effect on the height of tallest sucker at flowering of the plant crop. Vertical bar represents $\mathrm{LSD}_{0.05}$ 

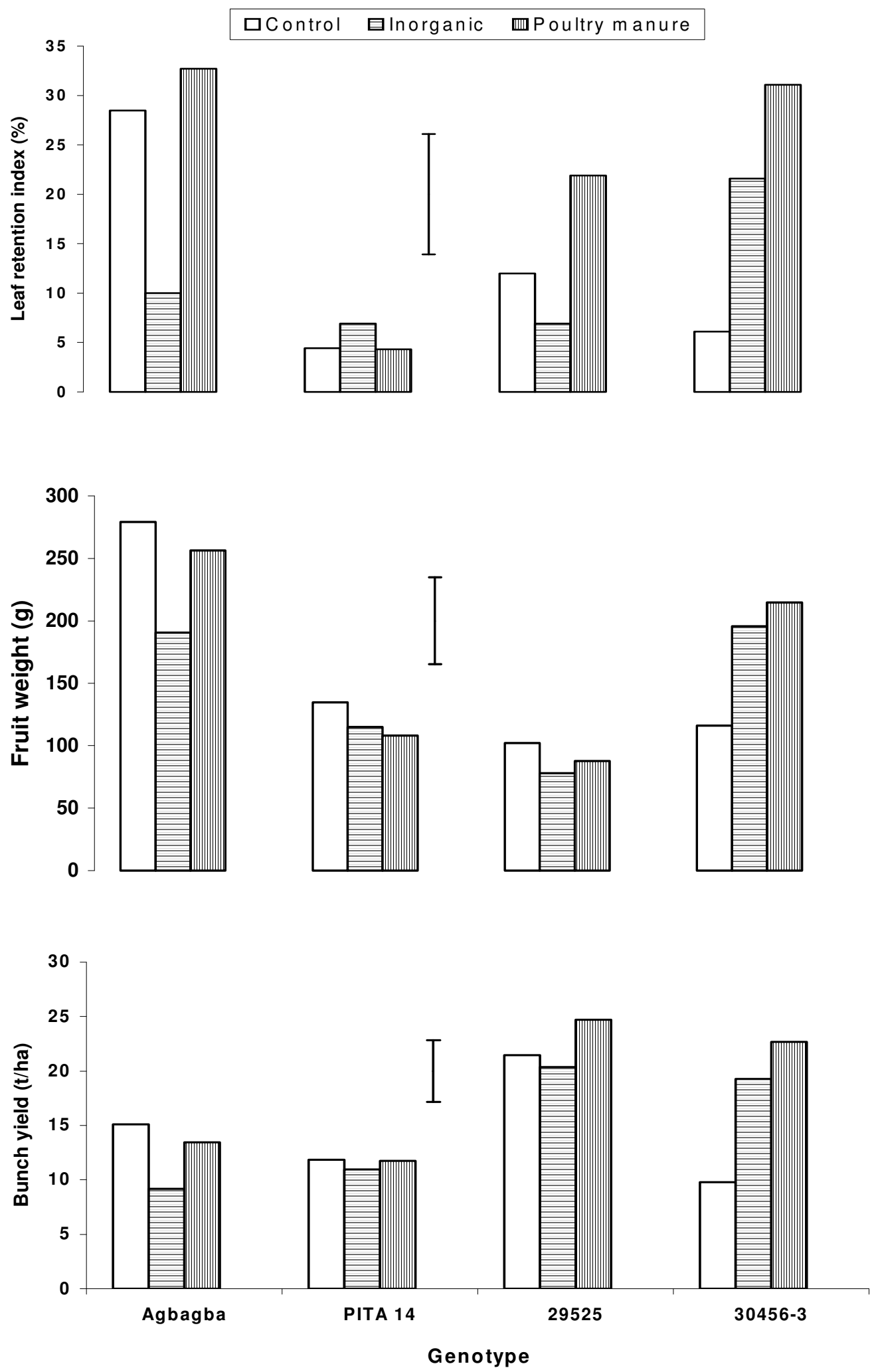

Fig. 2: Genotype and fertilizer type interaction effect on (a) leaf retention index (b) fruit weight (c) bunch yield. Vertical bars represent $\mathrm{LSD}_{0.05}$ 
Ndukwe, O. O., Muoneke, C. O. Baiyeri, K. P. and Tenkouano, A.

Interaction effect: The leaf retention index, fruit weight and bunch yield per hectare were influenced by the combined effects of fertilizer type and genotypes (Fig. 2). The landrace, 'Agbagba' had higher value for leaf retention index than the hybrids when it received organic fertilizer or no fertilizer. Similarly heavier fruit weight was associated with 'Agbagba' irrespective of the fertilizer type. Among the hybrids, leaf retention index and fruit weight increased with the application of fertilizer in '30456-3'. The values were greater when the plant received organic fertilizer. However, '29525' produced higher bunch yield per hectare than the other genotypes irrespective of the fertilizer type.

Effect of Cropping Cycle: The black sigatoka disease resistance/tolerance traits (index of non-spotted leaves, youngest leaf spotted and number of standing leaves at harvest) were higher in the plant crop than the ratoon crop (Table 7). However, plant height and girth (at flowering), bunch yield per hectare, number of fruits per bunch and fruit weight were higher in the ratoon crop than the plant crop. The height of tallest sucker at flowering, total leaf weight at harvest and leaf retention index were similar in the two cropping cycles (Table 7).

Correlation analysis of index of non-spotted leaves at flowering and some growth and yield parameters at harvest: In the plant crop, index of non-spotted leaves at flowering had positive and significant correlation with all the growth and yield parameters at harvest (Table 8). The yield parameters - bunch yield/ha, number of fruits/bunch and fruit weight had relatively higher relationship with the index of non-spotted leaves than the growth parameters. However, the bunch yield/ha $\left(r=0.756^{* *}\right)$ had stronger association with the index of non-spotted leaves than number of fruits $\left(\mathrm{r}=0.560^{* *}\right)$ and fruit weight $\left(\mathrm{r}=0.523^{* *}\right)$. In the ratoon crop, the bunch yield/ha and total leaf weight had positive and significant association with the index of nonspotted leaves. The fruit weight was negatively associated with the black sigatoka disease response parameter.

Table 3: Main effects of genotype and fertilizer type on growth at 3 and 6 MAP of the plant crop

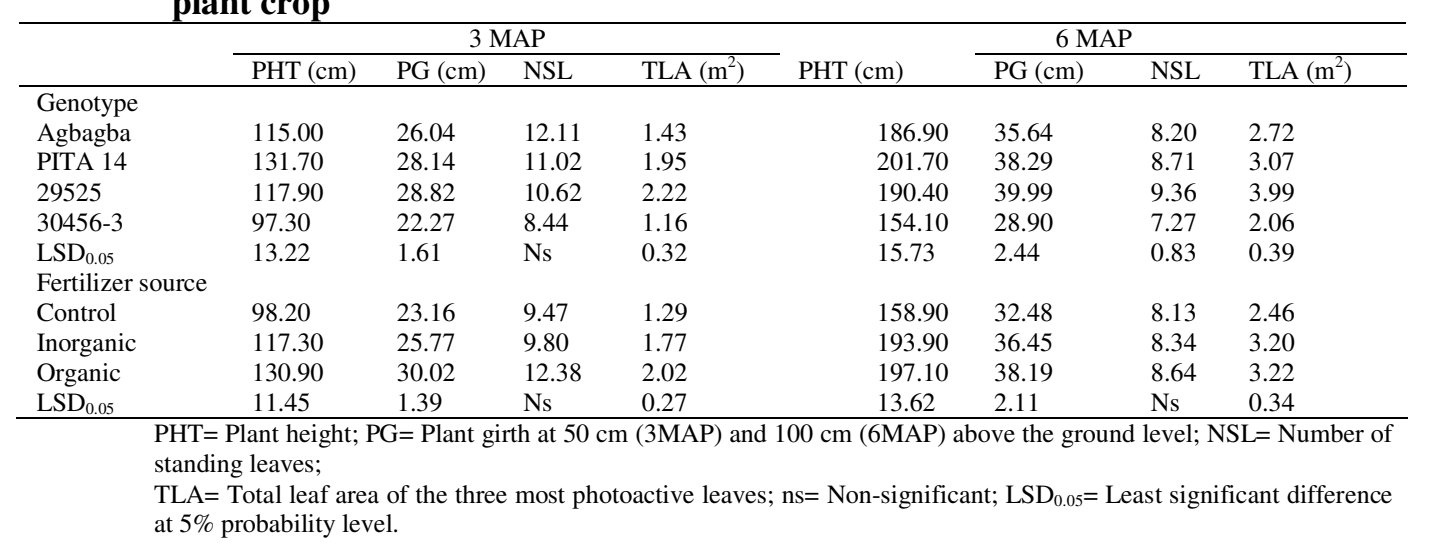

Table 4: Main effects of genotype and fertilizer type on the growth and black sigatoka disease at flowering of the plant and ratoon crops.

\begin{tabular}{|c|c|c|c|c|c|c|c|c|c|c|}
\hline & \multicolumn{5}{|c|}{ Plant crop } & \multicolumn{5}{|c|}{ Ratoon crop } \\
\hline & $\begin{array}{l}\text { Plant height } \\
(\mathrm{cm})\end{array}$ & $\begin{array}{l}\text { Plant } \\
\text { girth } \\
(\mathrm{cm})\end{array}$ & $\begin{array}{l}\text { INSL } \\
(\%)\end{array}$ & $\begin{array}{l}\text { Youngest } \\
\text { leaf } \\
\text { spotted }\end{array}$ & $\begin{array}{l}\text { Height of } \\
\text { tallest } \\
\text { sucker } \\
(\mathrm{cm})\end{array}$ & $\begin{array}{l}\text { Plant } \\
\text { height } \\
(\mathrm{cm})\end{array}$ & $\begin{array}{l}\text { Plant } \\
\text { girth } \\
(\mathrm{cm})\end{array}$ & $\begin{array}{l}\text { INSL } \\
(\%)\end{array}$ & $\begin{array}{l}\text { Youngest } \\
\text { leaf } \\
\text { spotted }\end{array}$ & $\begin{array}{l}\text { Height of } \\
\text { tallest } \\
\text { sucker } \\
(\mathrm{cm})\end{array}$ \\
\hline \multicolumn{11}{|l|}{ Genotype } \\
\hline Agbagba & 321.30 & 53.11 & 66.28 & 8.30 & 169.30 & 373.00 & 62.16 & 54.60 & 5.86 & 112.50 \\
\hline PITA 14 & 265.50 & 44.65 & 78.08 & 9.74 & 149.10 & 365.50 & 62.87 & 69.53 & 8.36 & 184.10 \\
\hline 29525 & 236.70 & 45.79 & 77.74 & 9.15 & 136.50 & 315.90 & 63.19 & 61.71 & 7.05 & 177.00 \\
\hline $30456-3$ & 277.60 & 42.84 & 74.65 & 8.77 & 179.90 & 302.90 & 48.42 & 67.16 & 7.01 & 120.10 \\
\hline $\mathrm{LSD}_{0.05}$ & 18.05 & 5.15 & 4.75 & Ns & 31.23 & 16.25 & 3.77 & 4.52 & 0.93 & 36.50 \\
\hline \multicolumn{11}{|l|}{$\begin{array}{l}\text { Fertilizer } \\
\text { source }\end{array}$} \\
\hline Control & 281.80 & 45.85 & 69.86 & 7.79 & 172.10 & 325.40 & 55.91 & 62.69 & 6.66 & 136.30 \\
\hline Inorganic & 273.20 & 46.52 & 74.45 & 8.74 & 156.20 & 341.50 & 59.61 & 61.67 & 6.97 & 162.70 \\
\hline Organic & 270.90 & 47.43 & 78.25 & 10.44 & 147.70 & 351.00 & 61.96 & 65.39 & 7.58 & 146.30 \\
\hline $\mathrm{LSD}_{0.05}$ & ns & ns & 4.11 & 1.17 & Ns & 14.08 & 3.26 & Ns & ns & ns \\
\hline
\end{tabular}


Effects of Organic and Inorganic Fertilizers on Plantain genotypes

Table 5: Genotype and fertilizer type interaction effect on plantain growth at 3 and 6 MAP of the plant crop.

\begin{tabular}{|c|c|c|c|c|c|c|c|c|c|}
\hline \multirow{3}{*}{$\begin{array}{l}\text { Fertilizer } \\
\text { type } \\
\text { Control }\end{array}$} & \multicolumn{4}{|c|}{3 MAP } & \multicolumn{5}{|c|}{$6 \mathrm{MAP}$} \\
\hline & Genotype & $\begin{array}{l}\text { PHT } \\
(\mathrm{cm})\end{array}$ & $\begin{array}{l}\text { PG } \\
(\mathrm{cm})\end{array}$ & NSL & $\begin{array}{l}\text { TLA } \\
\left(\mathrm{m}^{2}\right)\end{array}$ & $\begin{array}{l}\text { PHT } \\
(\mathrm{cm})\end{array}$ & $\begin{array}{l}\begin{array}{l}\text { PG } \\
(\mathrm{cm})\end{array} \\
\end{array}$ & NSL & TLA $\left(\mathrm{m}^{2}\right)$ \\
\hline & Agbagba & 102.00 & 23.22 & 9.73 & 1.18 & 175.00 & 33.07 & 8.47 & 2.46 \\
\hline & PITA 14 & 121.00 & 25.87 & 10.93 & 1.71 & 181.00 & 36.82 & 8.80 & 2.85 \\
\hline & 29525 & 91.70 & 23.57 & 9.47 & 1.45 & 153.30 & 34.91 & 8.47 & 2.99 \\
\hline & $30456-3$ & 78.00 & 19.98 & 7.73 & 0.82 & 126.30 & 25.14 & 6.80 & 1.55 \\
\hline \multirow[t]{4}{*}{ Inorganic } & Agbagba & 110.00 & 25.12 & 9.60 & 1.33 & 189.00 & 35.60 & 8.00 & 2.73 \\
\hline & PITA 14 & 134.00 & 27.70 & 10.67 & 1.93 & 216.00 & 38.80 & 8.47 & 3.32 \\
\hline & 29525 & 129.70 & 30.13 & 10.27 & 2.68 & 209.70 & 42.47 & 9.80 & 4.69 \\
\hline & $30456-3$ & 95.70 & 20.13 & 8.27 & 1.12 & 160.80 & 28.92 & 7.08 & 2.08 \\
\hline \multirow[t]{4}{*}{ Organic } & Agbagba & 133.00 & 29.78 & 17.00 & 1.78 & 196.70 & 38.27 & 8.13 & 2.97 \\
\hline & PITA 14 & 140.00 & 30.85 & 11.47 & 2.22 & 208.00 & 39.27 & 8.87 & 3.04 \\
\hline & 29525 & 132.30 & 32.75 & 11.73 & 2.52 & 208.30 & 42.60 & 9.80 & 4.31 \\
\hline & $30456-3$ & 118.30 & 26.70 & 9.33 & 1.55 & 175.20 & 32.63 & 7.92 & 2.57 \\
\hline $\mathrm{LSD}_{0.05}$ & & Ns & 2.79 & $\mathrm{~ns}$ & Ns & Ns & Ns & ns & 0.68 \\
\hline
\end{tabular}

Table 6: Main effects of genotype and fertilizer type on bunch yield and some other parameters at harvest of the plant and ratoon crops

\begin{tabular}{|c|c|c|c|c|c|c|c|c|c|c|c|c|}
\hline \multirow[b]{3}{*}{ Genotype } & \multicolumn{4}{|c|}{ Plant crop } & \multicolumn{8}{|c|}{ Ratoon crop } \\
\hline & $\begin{array}{c}\text { No. of } \\
\text { standing } \\
\text { leaves }\end{array}$ & $\begin{array}{l}\text { Total wt } \\
\text { of } \\
\text { standing } \\
\text { leaves } \\
\text { (kg) }\end{array}$ & $\begin{array}{l}\text { Leaf } \\
\text { retention } \\
\text { index } \\
(\%)\end{array}$ & $\begin{array}{c}\text { No. } \\
\text { of } \\
\text { fruits/bunch }\end{array}$ & $\begin{array}{c}\text { Fruit } \\
\text { weight } \\
\text { (g) }\end{array}$ & $\begin{array}{l}\text { Bunch } \\
\text { yield } \\
\text { (t/ha) }\end{array}$ & $\begin{array}{c}\text { No. } \\
\text { of } \\
\text { standing } \\
\text { leaves }\end{array}$ & $\begin{array}{l}\text { Total wt } \\
\text { of } \\
\text { standing } \\
\text { leaves } \\
(\mathrm{kg})\end{array}$ & $\begin{array}{l}\text { Leaf } \\
\text { retention } \\
\text { index } \\
(\%)\end{array}$ & $\begin{array}{l}\text { No. of } \\
\text { fruits/ } \\
\text { bunch }\end{array}$ & $\begin{array}{c}\text { Fruit } \\
\text { weight } \\
\text { (g) }\end{array}$ & $\begin{array}{l}\text { Bunch } \\
\text { yield } \\
\text { (t/ha) }\end{array}$ \\
\hline & & & & & & & & & & & & \\
\hline Agbagba & 2.72 & 1.78 & 12.57 & 26.60 & 239.00 & 12.57 & 1.27 & 1.08 & 14.10 & 26.80 & 312.60 & 15.15 \\
\hline PITA 14 & 0.63 & 0.29 & 11.52 & 62.50 & 119.30 & 11.52 & 0.86 & 1.00 & 7.60 & 108.00 & 173.60 & 28.10 \\
\hline 29525 & 1.47 & 1.06 & 13.60 & 161.80 & 89.30 & 22.17 & 1.04 & 1.38 & 10.70 & 188.80 & 152.70 & 41.92 \\
\hline $30456-3$ & 2.14 & 1.99 & 19.60 & 59.40 & 175.50 & 17.24 & 2.14 & 2.29 & 25.80 & 71.20 & 186.20 & 22.54 \\
\hline $\mathrm{LSD}_{0.05}$ & 0.63 & 0.21 & 7.02 & 9.48 & 40.26 & 3.28 & Ns & Ns & 9.46 & 8.15 & 27.80 & 4.81 \\
\hline \multicolumn{13}{|l|}{$\begin{array}{l}\text { Fertilizer } \\
\text { source }\end{array}$} \\
\hline Control & 1.22 & 0.70 & 12.70 & 69.80 & 155.70 & 14.54 & 1.16 & 1.04 & 15.50 & 96.60 & 198.90 & 25.38 \\
\hline Inorganic & 1.36 & 1.18 & 11.30 & 78.20 & 144.80 & 14.94 & 1.04 & 1.18 & 10.10 & 98.40 & 196.70 & 25.87 \\
\hline Organic c & 2.65 & 1.96 & 22.50 & 84.70 & 166.70 & 18.14 & 1.78 & 2.09 & 18.10 & 101.10 & 223.20 & 29.53 \\
\hline $\mathrm{LSD}_{0.05}$ & 0.55 & 0.18 & 6.08 & 8.21 & Ns & 2.84 & Ns & Ns & Ns & ns & ns & Ns \\
\hline
\end{tabular}

PHT = Plant height; PG= Plant girth at $50 \mathrm{~cm}(3 \mathrm{MAP})$ and $100 \mathrm{~cm}(6 \mathrm{MAP})$ above the ground level; NSL= Number of standing

leaves; TLA $=$ Total leaf area of the three most photoactive leaves; ns= Non-significant; $L_{S D} D_{0.05}=$ Least significant difference at

$5 \%$ probability level

.Table 7: Effect of cropping cycle on the growth parameters at flowering and yield parameters at harvest.

\begin{tabular}{|c|c|c|c|c|c|c|c|c|c|c|c|}
\hline \multirow[b]{2}{*}{$\begin{array}{c}\text { Cropping } \\
\text { cycle }\end{array}$} & \multicolumn{5}{|c|}{ At flowering } & \multicolumn{6}{|c|}{ At harvest } \\
\hline & $\begin{array}{l}\text { Plant } \\
\text { height } \\
(\mathrm{cm})\end{array}$ & $\begin{array}{l}\text { Plant } \\
\text { girth } \\
(\mathrm{cm})\end{array}$ & $\begin{array}{l}\text { INSL } \\
(\%)\end{array}$ & $\begin{array}{l}\text { Youngest } \\
\text { leaf } \\
\text { spotted }\end{array}$ & $\begin{array}{l}\text { Height of } \\
\text { tallest } \\
\text { sucker } \\
(\mathrm{cm})\end{array}$ & $\begin{array}{l}\text { Bunch } \\
\text { yield } \\
\text { (t/ha) }\end{array}$ & $\begin{array}{l}\text { No. of } \\
\text { fruits } \\
\text { /bunch }\end{array}$ & $\begin{array}{l}\text { Fruit } \\
\text { weight } \\
\text { (g) }\end{array}$ & $\begin{array}{l}\text { No. of } \\
\text { standing } 1 \\
\text { eaves }\end{array}$ & $\begin{array}{l}\text { Total wt of } \\
\text { standing } \\
\text { leaves }(\mathrm{kg})\end{array}$ & $\begin{array}{l}\text { Leaf } \\
\text { retention } \\
\text { index } \\
(\%)\end{array}$ \\
\hline $\begin{array}{l}\text { Plant } \\
\text { crop }\end{array}$ & 275.20 & 46.58 & 74.17 & 9.03 & 157.90 & 9.44 & 76.8 & 155.90 & 1.79 & 1.32 & 14.79 \\
\hline $\begin{array}{l}\text { Ratoon } \\
\text { crop }\end{array}$ & 339.30 & 59.16 & 63.25 & 7.07 & 148.40 & 16.14 & 98.6 & 206.30 & 1.33 & 1.44 & 14.57 \\
\hline $\operatorname{LSD}_{0.05}$ & 2.83 & 0.75 & 0.77 & 0.19 & Ns & 1.20 & 4.28 & 15.88 & 0.45 & Ns & ns \\
\hline
\end{tabular}

INSL= Index of non-spotted leaves; ns= Non-significant; $\mathrm{LSD}_{0.05}=$ Least Significant Difference at $5 \%$ probability level. 
Table 8: Relationship between some growth and yield parameters at harvest and the index of non-spotted leaves at flowering in the plant and first ratoon crops

\begin{tabular}{lcc}
\hline Parameter & Plant crop & Ratoon crop \\
\hline Bunch yield (t/ha) & $0.756^{* *}$ & $0.341^{*}$ \\
Number of fruits/bunch & $0.560^{* *}$ & $0.266^{\mathrm{ns}}$ \\
Fruit weight & $0.523^{* *}$ & $-0.372^{*}$ \\
Leaf retention index & $0.426^{* *}$ & $0.261^{\mathrm{ns}}$ \\
Number of standing leaves & $0.436^{* *}$ & $0.323^{\mathrm{ns}}$ \\
Total leaf weight & $0.414^{* *}$ & 0.369 \\
\hline$* * *=$ Significant at 5\% and 1\% probability level, respectively &
\end{tabular}

\section{DISCUSSION}

The host plant resistance to the black sigatoka disease of the hybrids, especially '29525' and 'PITA 14' compared to the control, 'Agbagba' at 3 MAP, 6 MAP and at flowering was confirmed in this study. This is evidenced by their higher number of standing leaves (functional leaves) and index of nonspotted leaves. Significant fertilization effect on the growth and black sigatoka disease response parameters at $3 \mathrm{MAP}, 6 \mathrm{MAP}$ and flowering could be associated with the release of nutrients (especially nitrogen which is needed for growth by all plants) by the inorganic and organic fertilizers applied. A similar observation had been made in maize (Ayoola and Adeniyan, 2006). Organic fertilizer generally had higher performance in terms of plant height and girth, number of standing leaves and index of non-spotted leaves than inorganic fertilizer. Hue and Silva (2000) found that poultry manure provides a large quantity of nitrogen during the first four to six weeks after application. It had also been observed that the addition of manure increased the soil water holding capacity thereby enhancing sustained release of nutrients to crops where manure had been added to the soil (Costa et al., 1991). The height of tallest sucker was higher for ' $30456-3$ ' than the other genotypes irrespective of the fertilizer type. As it was observed during the experiment, the other genotypes produce higher number of suckers per stool than '30456-3' (data not shown). Hence there might be greater competition for nutrient, light, moisture between the several numbers of suckers of the other genotypes than the few suckers produced by ' $30456-3$ '.

As expected, the higher the number of functional leaves at harvest the higher the conversion of photoassimilates for dry matter production. The number of standing leaves and leaf retention index were highest for ' $30456-3$ ' yet it did not produce higher bunch yield per hectare. Genotype '29525' produced higher bunch yield per hectare. Obiefuna (1986) observed that rapidly growing banana fruits utilised nitrogen reserves for protein synthesis faster than they could be replenished resulting in reduced leaf longevity. Poultry manure retained higher number of leaves and had more total leaf weight and leaf retention index. These characteristics might have resulted in the higher bunch yield per hectare and heavier fruit weight as more photoassimilate should have been converted to dry matter. Leaf retention index increased with the application of fertilizer especially poultry manure. This means that leaf retention index is not only genotype specific but could be influenced by soil fertility dynamics. Mobambo et al. (1993) reported that organic nutrients from the disposal of household wastes might play a role in lowering black sigatoka severity on backyard plantains and bananas. Among the hybrids, the application of fertilizer to '304563 ' increased the leaf retention index and fruit weight. The values were greater when the plant received organic fertilizer.

The plant crops performed better in terms of index of non-spotted leaves at flowering, youngest leaf spotted at flowering and number of standing leaves at harvest. Oluma et al. (2004) observed that the severity of black sigatoka disease increased with age. Also the ratoon crops had their productive cycle in the same field with the plant crop hence, the virulent Mycosphaerella fijiensis must have been multiplied during the development of the ratoon crop which should have resulted in higher percentage of leaves (index of non-spotted leaves at flowering) with the fungal spores. However, plant height and girth (at flowering), bunch yield per hectare, number of fruits per bunch and fruit weight were higher in the ratoon crop than the plant crop. The ratoon crop benefited from the organic matter turnover of the plant crop in addition to the fertilizers received. This explains why the ratoon crop produced higher bunch yield, number of fruits per bunch and average fruit weight. Obiefuna (1990) observed the same result while working with a false horn plantain (Musa AAB cv Agbagba); Baiyeri and Tenkouano (2007) also reported similar result with ten Musa genotypes grown 
for two cropping cycles in south-eastern Nigeria.

Foliage traits and black sigatoka disease resistance status of plants at flowering were found to be strong and positively associated with bunch weight in high yielding Musa genotypes (Baiyeri et al., 2008). This explains why there was a strong and positive relationship between the index of non-

spotted leaves at flowering and bunch yield/ha. This suggests that increased percentage of nonspotted leaves increased the yield and yield components of the crops.

The results of the experiment suggest that none of the hybrids, especially the newly developed ones were severely infected by the black sigatoka disease since the value for their index of non-spotted leaves ranged between 62 to $78 \%$ across the two cropping cycles. The earlier finding that the black sigatoka disease severity could be reduced by soil fertility improvement was also confirmed. The two newest hybrids '30456-3' and '29525' had comparatively good agronomic traits that could warrant their recommendation for onfarm adaptive trial.

\section{REFERENCES}

Ayoola, O. I. and Adeniyan, O. N. (2006). Influence of poultry manure and NPK fertilizer on yield and yield components of crops under different cropping systems in southeastern Nigeria. African Journal of Biotechnology. Vol.5 (15). pp. 13861392.

Baiyeri, K. P. and Tenkouano, A. (2007). Fruit characteristics and ripening pattern of ten Musa genotypes in a sub-humid environment in Nigeria. Fruits, 63: 3-9.

Baiyeri, K. P. and Tenkouano, A. (2008). Manure placement effects on root and shoot growth and nutrient uptake of 'PITA 14' plantain hybrid (Musa sp. AAAB) African Journal of Agricultural Research. Vol. 3 (1): 013-021.

Baiyeri, K. P., M. Pillay and Tenkouano, A. (2008). Phenotypic relationships among growth, yield and black leaf streak disease responses of Musa genotypes. Journal of Crop Improvement. 21 (1): 41-54.

Costa, F. C., G. T. Hernandez, A. Polo (1991). Residous organicos urbanos. In: Manejoy Utilizacion, CSIC, Murrcia. $181 \mathrm{pp}$.
Craenen, K. (1998). Black Sigatoka disease of banana and plantain: a reference manual. International Institute of Tropical Agriculture, Ibadan, Nigeria. 60pp.

Englberger, L., R. B. H. Wills, B. Blades, L. Dufficy, J. W. Daniells and T. Coyne (2006). Carotenoid content and flesh colour of selected banana cultivars growing in Australia. Food and Nutrition Bulletin, vol. 27 (4):281291.

Food and Agriculture Organisation (2006). Food and Agriculture Organisation Statistical Databases (FAOSTAT). Available at http://apps.fao.org. Accessed 4 September 2006

GENSTAT (2003). GENSTAT 5.0. Release 4.23D, Discovery Edition 1, Lawes Agricultural Trust, Rothamsted Experimental station.

Hue, N. V. and J. A. Silva (2000). Organic soil amendments for sustainable agriculture: organic sources of nitrogen, phosphorus and potassium. In: J. A. Silva and R. Uchida (eds.). Plant Nutrient Management in Hawaii's soils; Approaches for Tropical and subtropical Agriculture. College of Tropical Agriculture and Human Resources, University of Hawaii at Manoa.

Mobambo, K. N., F. Gauhl, C. Pasberg-Gauhl (1993). Plantain response to black sigatoka in backyard gardens and fields in south-eastern Nigeria. MusAfrica 3: 3-4.

Mobambo, K.N., Zuofa, K., Gauhl,F. Adeniji, M.O. and Pasberg-Gauhl, C. (1994). Effect of soil fertility on host response to black leaf streak of plantain (Musa spp., ABB group) under traditional farming systems in southeastern Nigeria. International Journal of Pest Management, 40 (1): 75-80.

Obiefuna, J.C. (1984). Effect of K application during floral initiation stage of plantain (Musa ABB). Fertilizer Research, 5: 315-319.

Obiefuna, J. C. (1986). Growth and yield components as indices of bunch weights (yield) in plantains (Musa AAB). Paper presented at 22nd Annual Conference of Agricultural Society of Nigeria, 1st-3rd September, 1986 at Ahmadu Bello University, Zaria.

Obiefuna, J. C. (1990). Effect of manures and composts on nematodes, borer weevil and yield of plantain. Biological 
Agriculture and Horticulture, 6: 277 283.

Obiefuna, J. C. and Ndubizu, T. O. C. (1979). Estimating leaf area in plantains. Scientia Horticulturae, 11: 31-36.

Oluma, H. O. A., A. Onekutu, F. N. Onyezili (2004). Reactions of plantain and banana cultivars to black sigatoka leaf spot disease in three farming systems in the Nigerian guinea savanna. Journal of Plant Diseases and Protection. 111 (2), 158-164.

Ortiz, R., Austin, P. D. and Vuylsteke, D. (1997). IITA high rainfall station: Twenty years of research for sustainable agriculture in the West African humid forest. Hortscience, 32 (6): 969-972.

Pasberg-Gauhl, C., F. Gauhl and D. R. Jones (2000). Fungal diseases of the foliage. Sigatoka leaf spots. Black leaf streak. Districution and economic importance. In: Diseases of banana, abaca and enset (D. R. Jones, ed.). CABI Publishing. pp. 37-44.

Rhodes, P. L. (1964). A new banana disease in Fiji. Commonwealth Phytopathology News. 10: 38-41.
SPPS (2006). SPSS 15.0 for Windows Evaluation version, Release 15.0.0. SPSS Inc.

Swennen, R. (1990). Plantain Cultivation under West African Conditions: A Reference Manual. IITA, Ibadan, Nigeria. 24pp.

Swennen, R. and De Langhe, E. (1985). Growth Parameters of Yield of Plantain (Musa cv. AAB). Annals of Botany. 56: 197-204.

Tomekpé, K., P. Noupadja, C. Abadie, J. Tchango-Tchango and E. Youmbi (1999). Amélioration génétique des plantains pour la sécurité alimentaire et l'export. Biosciences proceedings. 6: 444-454.

Vuylsteke, D, Ortiz, R. and Swennen, R. (1993). Genetic improvement of plantains and bananas at IITA. Infomusa. 2 ( 1): 10-12 